\title{
Gamma-heavy chain monoclonal gammopathy with undetermined significance (MGUS)
}

\author{
Yuriko Zushi, ${ }^{1)}$ Miho Sasaki, ${ }^{1)}$ Toshiharu Saitoh, ${ }^{1)}$ Yumi Aoyama, ${ }^{2)}$ Yuta Gotoh, \\ Hiroko Tsunemine, ${ }^{2)}$ Taiichi Kodaka, ${ }^{2)}$ Atsuo Okamura, ${ }^{3)}$ Takayuki Takahashi ${ }^{2)}$
}

Gamma-heavy chain disease $(\gamma-\mathrm{HCD})$ is a rare B-cell tumor producing truncated IgG lacking the light chain. The clinical features of $\gamma$-HCD are heterogeneous, similar to lymphoplasmacytic lymphoma, and most patients have generalized and progressive disease. In some $\gamma$-HCD patients, autoimmune diseases are associated. Thus, $\gamma$-HCD as a restricted or indolent disease is exceptional. A 66-year-old male was referred to our hospital because of subungual hemorrhage at the bilateral halluces. Physical and laboratory examination results were nonspecific, and the hemorrhage was revealed to be traumatic. However, serum electrophoresis demonstrated a small M-peak, which was monoclonal IgG-Fc without the corresponding light chain on immunofixation and immunoelectrophoresis. Bone marrow aspirate demonstrated a small number of lymphoplasmacytic cells that were positive for CD19, CD38, CD138, and cyIgG, but negative for cyк- and - $\lambda$ light chains on flow cytometry. A diagnosis of $\gamma$-HCD was made. Chest and abdominal CT demonstrated neither hepatosplenomegaly, lymphadenopathy, nor bone lytic lesions. The serum concentrations of IgG and M-peak configuration have remained relatively unchanged for nearly 3 years. Therefore, this $\gamma$-HCD may correspond to a rare form of monoclonal gammopathy with undetermined significance.

Keywords: $\gamma$-heavy chain disease, IgG-Fc, M-protein, monoclonal gammopathy with undetermined significance, lymphoplasmacytic cell

\section{INTRODUCTION}

Gamma heavy chain disease $(\gamma$-HCD) is a B-cell neoplasm that produces an abnormal $\gamma$-heavy chain lacking the corresponding light chain, being composed of Fc and truncated Fab components. ${ }^{1-3}$ The truncation in the heavy chain, which prevents the light chain from binding, is caused by the deletion of the CH1 domain in all $\gamma$-HCD and $\alpha$-HCD cases. ${ }^{4,5}$ The absence of the $\mathrm{CH} 1$ domain prevents the interaction with the immunoglobulin binding protein, leading to the secretion of free heavy chain in the absence of light chain synthesis. ${ }^{4,5}$ $\gamma$-HCD is rare, with approximately 150 cases having been reported to date. ${ }^{3}$ The clinical features of $\gamma$-HCD as a B-cell tumor are heterogeneous, resembling diseases, such as marginal zone lymphoma, plasmacytoma, lymphoplasmacytic lymphoma, and chronic lymphocytic leukemia, being a generalized and progressive disease., ${ }^{3,6}$ Association with autoimmune disease has been reported in $25-70 \%$ of $\gamma$-HCD cases, with rheumatoid arthritis (RA) and systemic lupus erythematosus (SLE) being the most common. ${ }^{6-8}$
As unusual forms of $\gamma$-HCD, localized and indolent diseases have been previously reported. ${ }^{6}$ Of these forms, rare clinical courses of $\gamma$-HCD, exhibiting monoclonal gammopathy of undetermined significance (MGUS), have been observed in 4 patients. ${ }^{6,9-11}$ Regarding $\mu$-heavy chain disease, a patient presenting the clinical features of benign monoclonal gammopathy, which is, in general, the same as MGUS, was previously reported. ${ }^{12}$ Here, we report a case of $\gamma$-heavy chain MGUS.

\section{CASE REPORT}

A 66-year-old male was referred to our hospital for subungual hemorrhage at the bilateral halluces. Physically, no bleeding was noted except for the subungual hemorrhage. Other physical examinations, including possible superficial lymph node swelling, were nonspecific. Laboratory findings are shown in Table 1. The platelet count was $182 \times 10^{9} / \mathrm{L}$ and hemostat results were normal. Screening tests for autoimmune disease, including antinuclear antibody, complements

Received: February 19, 2019. Revised: May 23, 2019. Accepted: May 29, 2019. J-STAGE Advance Published: August 8, 2019

DOI: $10.3960 /$ jslrt. 19008

${ }^{1}$ Departments of Cell Therapy and ${ }^{2}$ Hematology, Shinko Hospital, Kobe, Japan, ${ }^{3}$ Department of Hematology, Kakogawa City General Hospital, Kakogawa, Hyogo, Japan

Corresponding author: Takayuki Takahashi, Department of Hematology, Shinko Hospital, 4-47, Wakihama-cho, 1-chome, Chuo-ku, Kobe 651-0072, Japan.

E-mail: takahashi.takayuki@shinkohp.or.jp

Copyright (C) 2019 The Japanese Society for Lymphoreticular Tissue Research

(cc) BY-NC-SA This work is licensed under a Creative Commons Attribution-NonCommercial-ShareAlike 4.0 International License. 
(C3 and C4), myeloperoxidase (MPO)-anti-neutrophil cytoplasmic antibody (ANCA), and proteinase 3 (PR3)-ANCA, were all nonspecific. Serological tests for Epstein-Barr virus were negative. The subungual hemorrhage was later found to be traumatic.

An M-peak (Figure 1A) was observed on serum electrophoresis demonstrating monoclonal IgG without the light chain (Figure 1B) by serum immunofixation. The monoclonal
IgG lacking the light chain was also detected by urine immunofixation (Figure 1C). Serum immunoelectrophoresis demonstrated IgG M-bow without the corresponding light chain, and the monoclonal $\gamma$-heavy chain was revealed to be an IgG-Fc fragment (Figure 2).

The bone marrow aspirate exhibited a normal nucleated cell $(\mathrm{Ncc})$ count $\left(79.3 \times 10^{9} / \mathrm{L}\right)$ and normal granuloid erythroid ratio (2.6); however, small-sized lymphoplasmacytic cells,

Table 1. Laboratory data at presentation

\begin{tabular}{|c|c|c|c|c|c|}
\hline \multicolumn{2}{|c|}{ [Hematology] } & \multicolumn{2}{|c|}{ [Chemistry] } & \multicolumn{2}{|c|}{ [Serology] } \\
\hline $\mathrm{RBC}$ & $4,520 \times 10^{9} / \mathrm{L}$ & T-BiL & $0.7 \mathrm{mg} / \mathrm{dL}$ & CRP & $0.11 \mathrm{mg} / \mathrm{dL}$ \\
\hline $\mathrm{Hb}$ & $15.2 \mathrm{~g} / \mathrm{dL}$ & AST & $12 \mathrm{IU} / \mathrm{L}$ & $\mathrm{TP}$ & $6.3 \mathrm{~g} / \mathrm{dL}$ \\
\hline $\mathrm{Ht}$ & $44.5 \%$ & ALT & $10 \mathrm{IU} / \mathrm{L}$ & ALB & $68.6 \%$ \\
\hline PLT & $182 \times 10^{9} / \mathrm{L}$ & ALP & $218 \mathrm{IU} / \mathrm{L}$ & $\mathrm{A} / \mathrm{G}$ & 2.18 \\
\hline WBC & $3.7 \times 10^{9} / \mathrm{L}$ & $\mathrm{LDH}$ & $151 \mathrm{IU} / \mathrm{L}$ & $\operatorname{IgG}$ & $1,347 \mathrm{mg} / \mathrm{dL}$ \\
\hline $\mathrm{Neu}$ & $44.0 \%$ & $\gamma$-GTP & $32 \mathrm{IU} / \mathrm{L}$ & $\operatorname{IgA}$ & $97.0 \mathrm{mg} / \mathrm{dL}$ \\
\hline Eos & $0.5 \%$ & BUN & $19.0 \mathrm{mg} / \mathrm{dL}$ & $\operatorname{IgM}$ & $59.0 \mathrm{mg} / \mathrm{dL}$ \\
\hline Bas & $2.5 \%$ & Cre & $0.66 \mathrm{mg} / \mathrm{dL}$ & $\mathrm{RF}$ & $(-)$ \\
\hline Mon & $8.0 \%$ & CK & $43 \mathrm{IU} / \mathrm{L}$ & ANA & $<40$ \\
\hline Lym & $45.0 \%$ & AMY & $99 \mathrm{IU} / \mathrm{L}$ & $\mathrm{C} 3$ & $81.0 \mathrm{mg} / \mathrm{dL}$ \\
\hline \multicolumn{2}{|c|}{ [Hemostat test] } & UA & $4.5 \mathrm{mg} / \mathrm{dL}$ & $\mathrm{C} 4$ & $17.2 \mathrm{mg} / \mathrm{dL}$ \\
\hline PT-INR & 0.95 & T-Cho & $144 \mathrm{mg} / \mathrm{dL}$ & MPO-ANCA & $<1.0 \mathrm{U} / \mathrm{mL}$ \\
\hline APTT & $27.2 \mathrm{Sec}$ & TG & $173 \mathrm{mg} / \mathrm{dL}$ & PR3-ANCA & $<1.0 \mathrm{U} / \mathrm{mL}$ \\
\hline Fib & $262 \mathrm{mg} / \mathrm{dL}$ & $\mathrm{BS}$ & $136 \mathrm{mg} / \mathrm{dL}$ & EBV & Uninfected \\
\hline D-dimer & $0.6 \mu \mathrm{g} / \mathrm{mL}$ & & & Urinalysis & Non-specific \\
\hline
\end{tabular}

RF: rheumatoid factor; ANA: antinuclear antibody; MPO-ANCA: myeloperoxidase-anti-neutrophil cytoplasmic antibody; PR3: proteinase3; EBV: Epstein-Barr virus

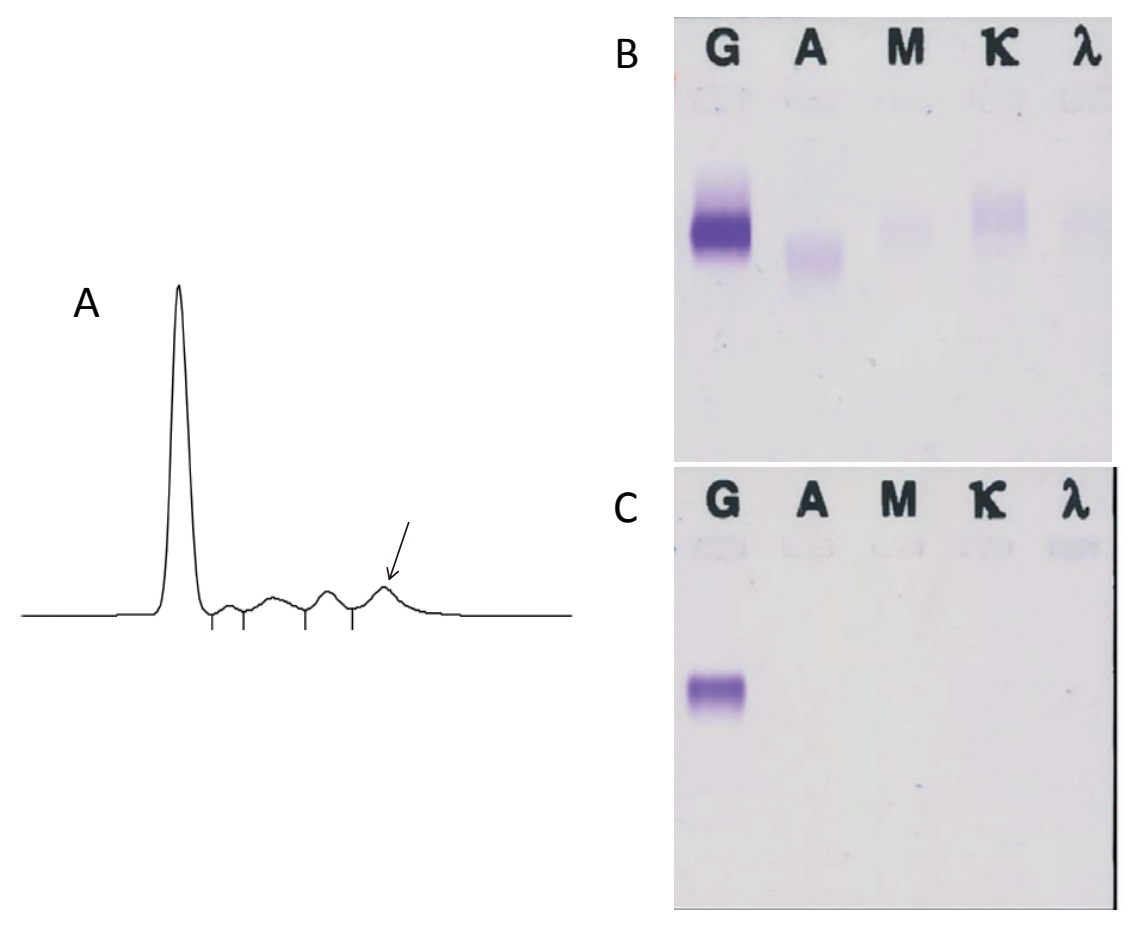

Fig. 1. Serum electrophoresis and immunofixation of the serum and urine. A small M-peak was seen $(\boldsymbol{A})$ (arrow), which was revealed to be monoclonal IgG lacking the light chain $(\boldsymbol{B})$. The monoclonal IgG without the light chain was also observed in the urine $(\boldsymbol{C})$. 
which comprised $2.8 \%$ of Ncc, were observed (Figure 3 ). On flow cytometry (FCM) analysis these lymphoplasmacytic cells were positive for CD19, CD38, CD79a, CD138, HLA-DR, and cy $\gamma$ (Figure 4), but negative for CD56, sm $\gamma / \mu$ / $\alpha / \delta, \operatorname{cy} \mu / \alpha / \delta$, and сук/ $\lambda$. In detail, CD19-positive cells composed $3.6 \%$ of $\mathrm{Ncc}$, and $\mathrm{CD} 38^{\text {bright }} / \mathrm{CD} 138^{+}$cells were tumor cells comprising $55.1 \%$ of CD $19^{+}$cells (Figure 4, bottom, left). The anti- $\gamma$ antibody used for this analysis was a polyvalent antibody (Nippon Becton Dickinson Company, Ltd., Tokyo, Japan). Multiplex PCR analysis for monoclonal rearrangement of the immunoglobulin heavy chain $(\mathrm{IgH})$ gene was negative, possibly due to the low frequency of these lymphoplasmacytic cells. Thus, a diagnosis of $\gamma-\mathrm{HCD}$ was made.

The patient remained asymptomatic, and no lymph node swelling, tumoral lesions, bone lytic lesions, or hepatosplenomegaly was observed on CT from the neck to whole abdomen. The serum IgG level and electrophoresis did not markedly change from May 2016 to February, 2019, as shown in Figure 5, although slight increases in the serum IgG level and size of the M-peak were observed. Serum free $\kappa$ and $\lambda$ chain concentrations were $9.24 \mathrm{mg} / \mathrm{L}$ (normally 3.5 to $19.4 \mathrm{mg} / \mathrm{L}$ ) and $12.1 \mathrm{mg} / \mathrm{L}$ (normally 5.7 to $26.3 \mathrm{mg} / \mathrm{L}$ ), respectively, with a $\kappa / \lambda$ ratio of 0.76 (normally 0.26 to 1.65 ). The patient was asymptomatic as of February 2019.

\section{DISCUSSION}

$\gamma$-HCD is a mostly generalized disease involving the lymph nodes, Waldeyer ring, gastrointestinal tract, bone marrow, liver, spleen, and peripheral blood, being frequently associated with autoimmune disease. ${ }^{6-8}$ Most $\gamma$-HCD patients also have systemic symptoms such as appetite loss, fatigue, fever, and weight loss. ${ }^{3,6}$ Restricted $\gamma$-HCD is rare, accounting for approximately $25 \%$ of $\gamma$-HCD cases, and the skin, thyroid gland, parotid gland, and pharyngeal cavity were reported as involved organs. ${ }^{6,13}$

Among the exceptional features of restricted and indolent $\gamma$-HCD, ${ }^{3,6}$ a rare form of $\gamma$-HCD MGUS has been described in 4 patients. ${ }^{6,9-11}$ In these patients, a small number of tumor cells were restricted in the bone marrow with an indolent clinical course. They did not have autoimmune disease. Regarding the clinical features of the present patient, he did not have systemic symptoms or autoimmune disease. The tumor cells that produced the truncated $\gamma$-heavy chain were restricted to the bone marrow comprising $2.8 \%$ of lymphoplasmacytic cells. Serum levels of IgG and M-peak on serum electrophoresis have remained stable for nearly 3

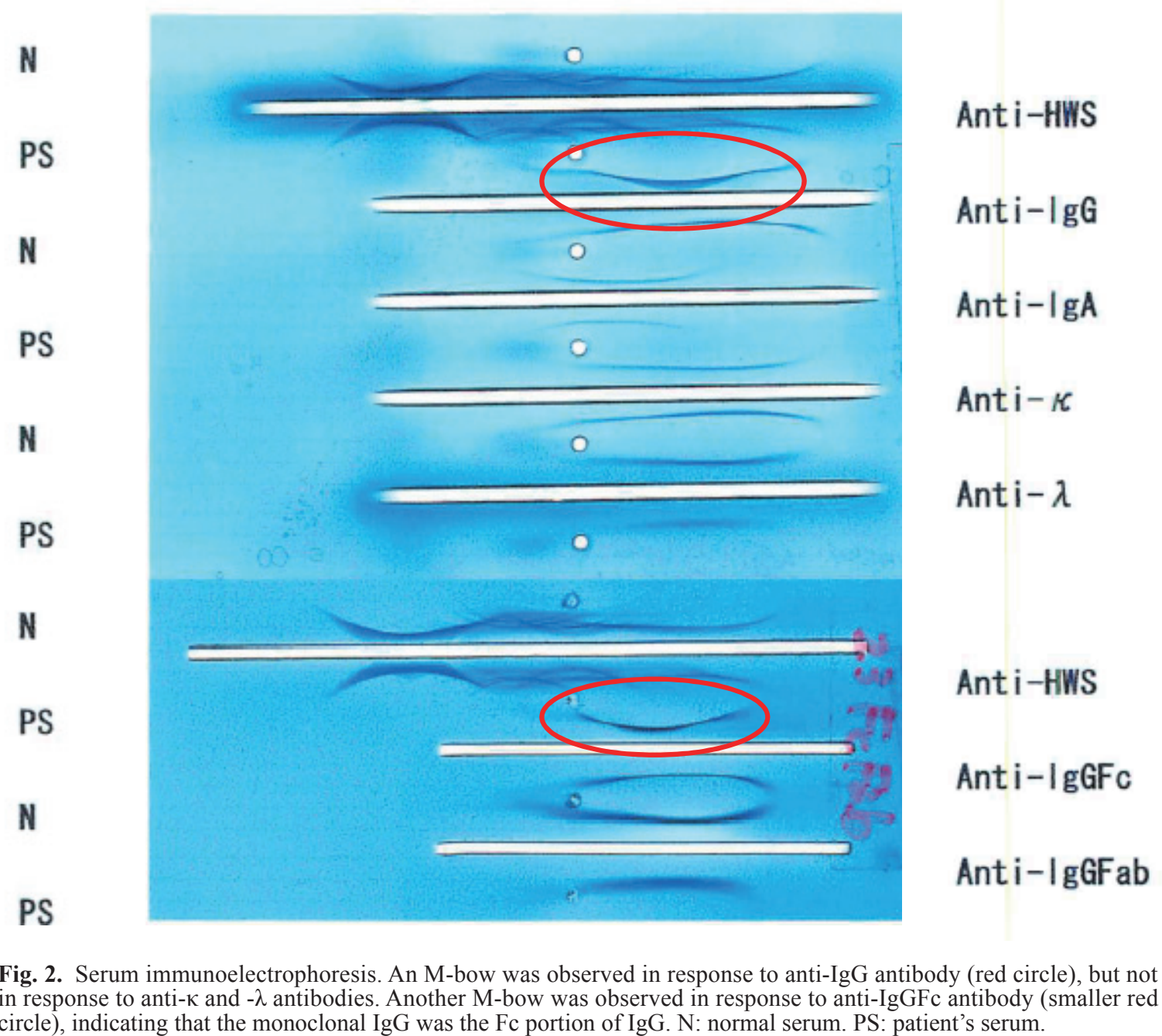
in response to anti- $\kappa$ and $-\lambda$ antibodies. Another M-bow was observed in response to anti-IgGFc antibody (smaller red circle), indicating that the monoclonal IgG was the Fc portion of IgG. N: normal serum. PS: patient's serum. 


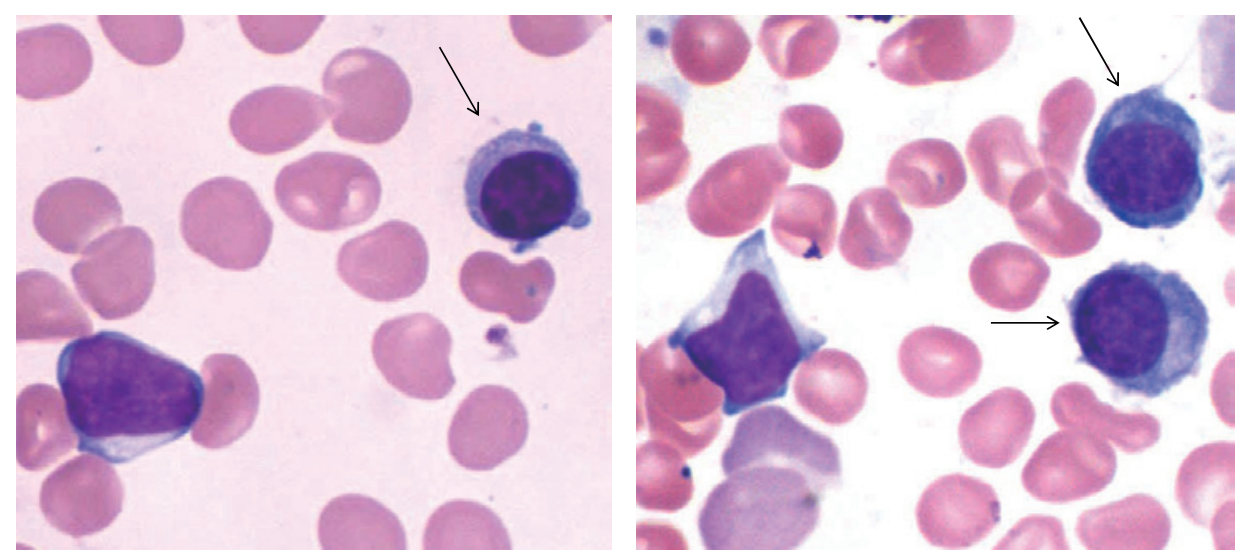

Fig. 3. Lymphoplasmacytic cells in the bone marrow (arrows). They were small and comprised $2.8 \%$ of marrow nucleated cells based on morphological evaluation $(\times 1,000$, Wright-Giemsa staining).
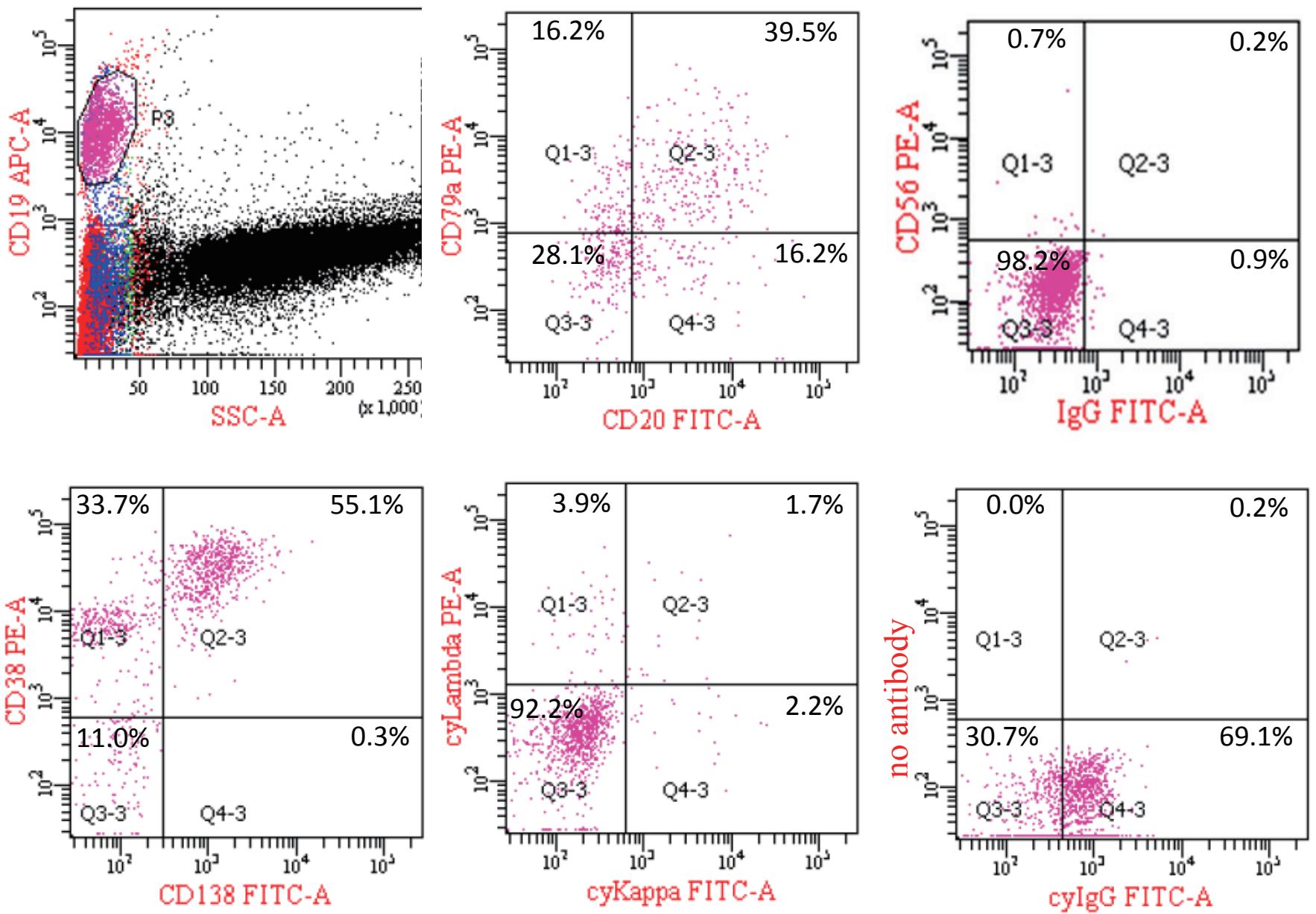

Fig. 4. Flow cytometry of the bone marrow cells. The analysis was performed with CD19-gating. CD19-positive cells comprised 3.6\% of the nucleated cells analyzed. The value in each area in respective cytograms means $\%$ of cells among CD19-positive cells. The CD19+ cells were positive for CD79a, CD138, CD38, and cyIgG, but negative for сук and cy light chains. Of these CD19-positive cells, CD38 ${ }^{\text {bright }} / \mathrm{CD} 138^{+}$ cells were considered tumor cells comprising $55.1 \%$ of the $\mathrm{CD} 19^{+}$cells (bottom, left). The analysis of cylgG was performed using a polyvalent anti-IgG antibody (Nippon Becton Dickinson Company, Ltd., Tokyo, Japan). We performed cytoplasmic Ig staining according to the following method: 1. wash marrow cells with PBS 4 times, 2. react the cells with an antibody for cell surface antigen in a 100- $\mu$ L tube for 15 min at room temperature, 3. treat the cells in $1.0 \mathrm{~mL}$ of PBS containing $0.5 \%$ paraformaldehyde and $0.5 \%$ saponin for 5 min at $4{ }^{\circ} \mathrm{C}$ for fixation, hemolysis, and pemeabilization, 4 . wash the cells once with PBS, 5. react the cells with an antibody for cytoplasmic antigen for 15 min at room temperature, 6 . wash the cells once with PBS, 7. measure the fluorescence intensity of surface and cytoplasmic antigens. 
May 2016

IgG

ND

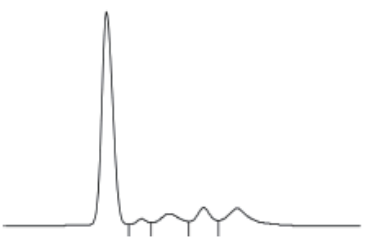

Nov 2016

$1,347 \mathrm{mg} / \mathrm{dL}$

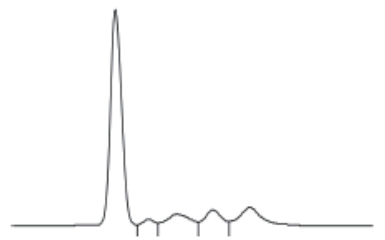

Jan 2019

$1,958 \mathrm{mg} / \mathrm{dL}$

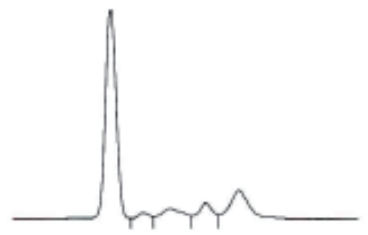

Fig. 5. Changes in the M-peak on serum electrophoresis and serum level of IgG over time. The size of the M-peak and IgG levels slightly increased over the 3-year period. ND: not done.

years. Based on findings, the present patient was diagnosed with $\gamma$-heavy chain MGUS, being the $5^{\text {th }}$ reported case.

In $\gamma$-HCD, the intracellular monoclonal $\gamma$-chain has been demonstrated by immunohistochemical methods but not by FCM. ${ }^{7}$ In the present case, we successfully detected the intracellular $\gamma$-chain by FCM, possibly being the first demonstration of the $\gamma$-chain in $\gamma$-HCD. The successful demonstration may be due to the polyvalent anti- $\gamma$ antibody used in this analysis. Monoclonal anti- $\gamma$ antibodies may fail to detect the intracellular $\gamma$-chain in some cases because the $\gamma$-chain is shorter (one half to three-quarters) than the normal $\gamma$-chain, ${ }^{2}$ and is thus an incomplete IgG heavy chain. Therefore, the polyvalent anti- $\gamma$ antibody may have the advantage of being able to detect the intracellular $\gamma$-chain in FCM analysis (personal communication). Although polyvalent antibodies may increase non-specific reactions, non-specific staining is unlikely because smIgG was clearly negative (Figure 4, upper, right), and the pattern of cyIgG positivity (Figure 4, bottom, right) was considered reasonable in the present analysis.

In conclusion, we report a $\gamma$-HCD patient whose clinical features were consistent with MGUS. The total of 5 reported cases of $\gamma$-heavy chain MGUS, including the present case, suggests the presence of a new clinical entity of $\gamma$-HCD.

\section{ACKNOWLEDGMENTS}

The authors are grateful to Miss Mizue Higashi for her excellent support in preparing the manuscript and literature search.

\section{CONFLICT OF INTEREST}

The authors declare no conflict of interest regarding this study.

\section{REFERENCES}

1 Osserman EF, Takatsuki K. Clinical and immunochemical studies of four cases of heavy (H-gamma-2) chain disease. Am J Med. 1964; $37:$ 351-373.
2 Wahner-Roedler DL, Kyle RA. Heavy chain diseases. Best Pract Res Clin Haematol. 2005; 18 : 729-746.

3 Cook JR, Harris NL, Isaacson PG, Jaffe ES. Heavy chain diseases; WHO Classification of Tumours of Haematopoietic and Lymphoid Tissues, World Health Organization. 4th ed, France, International Agency for Research on Cancer. 2017; pp. 237-240.

4 Cogné M, Silvain C, Khamlichi AA, Preud'homme J-L. Structurally abnormal immunoglobulins in human immunoproliferative disorders. Blood. 1992; 79 : 2181-2195.

5 Cogné M, Aucouturier P, Brizard A, et al. Complete variable region deletion in a mu heavy chain disease protein (ROUL). Correlation with light chain secretion. Leuk Res. 1993; 17 : 527-532.

6 Wahner-Roedler DL, Witzig TE, Loehrer LL, Kyle RA. Gamma-heavy chain disease: review of 23 cases. Medicine (Baltimore). 2003; $82: 236-250$.

7 Bieliauskas S, Tubbs RR, Bacon CM, et al. Gamma heavychain disease: defining the spectrum of associated lymphoproliferative disorders through analysis of 13 cases. Am J Surg Pathol. 2012; 36 : 534-543.

8 Husby G, Blichfeldt P, Brinch L, et al. Chronic arthritis and gamma heavy chain disease: coincidence or pathogenic link? Scand J Rheumatol. 1998; 27 : 257-264.

9 Galanti LM, Doyen C, Vander Maelen C, et al. Biological diagnosis of a gamma-1-heavy chain disease in an asymptomatic patient. Eur J Haematol. 1995; 54 : 202-204.

10 Deighan WI, O'Kane MJ, McNicholl FP, Keren DF. Multiple myeloma and multiple plasmacytomas associated with free gamma heavy chain, free kappa light chain and IgGk paraproteins: an unusual triple gammopathy. Ann Clin Biochem. 2016; $53: 706-711$.

11 Van Keer J, Meijers B, Delforge M, Verhoef G, Poesen K. Two Cases of Heavy Chain MGUS. Case Rep Oncol Med. 2016; $2016: 8749153$.

12 Wahner-Roedler DL, Kyle RA. Mu-heavy chain disease: presentation as a benign monoclonal gammopathy. Am J Hematol. 1992; $40:$ 56-60.

13 Fermand JP, Brouet JC, Danon F, Seligmann M. Gamma heavy chain "disease": heterogeneity of the clinicopathologic features. Report of 16 cases and review of the literature. Medicine (Baltimore). 1989; $68:$ 321-335. 